\title{
Inhibin A Measurement
}

National Cancer Institute

\section{Source}

National Cancer Institute. Inhibin A Measurement. NCI Thesaurus. Code C82020.

The determination of the amount of inhibin A present in a sample. 